\title{
Jobs for Africa's expanding youth cohort: a stocktaking of employment prospects and policy interventions
}

\author{
Gordon Betcherman ${ }^{1 *}$ (D) and Themrise Khan ${ }^{2}$
}

\author{
* Correspondence: Gordon. \\ Betcherman@uottawa.ca \\ ${ }^{1}$ School of International \\ Development and Global Studies, \\ University of Ottawa, 120 University \\ Ottawa, Ottawa, ON K1M 1C5, \\ Canada \\ Full list of author information is \\ available at the end of the article
}

\begin{abstract}
Youth unemployment and underemployment are serious concerns in sub-Saharan Africa, especially given the region's young population. The barriers young people face stem both from skills deficiencies and from weak fundamentals that constrain job creation more generally in the region. Employment interventions can mitigate some of these barriers. However, our stocktaking of these interventions suggests that existing programs are disproportionately focused on the formal wage sector and do not adequately reflect the reality that most young people work in agriculture, household enterprises, and self-employment and will continue to do so for the foreseeable future. Finally, better data and evaluation are needed for more effective interventions.

JEL Classification: J08, J10, J21, J46

Keywords: Youth employment, Sub-Saharan Africa, Skills, Employment policy
\end{abstract}

\section{Introduction}

Youth employment is a pressing issue in sub-Saharan Africa (SSA). One reason is demography. This is the youngest region in the world, with a large youth bulge that will continue to expand rapidly in the future. The median age is 18 now and will climb to just 24 by 2050. The UN estimates that the size of the 15-24-year-old age group will increase by about six million annually over the next decade. This youthful profile offers the potential for a "demographic dividend", such as the one that benefited East Asia in the late twentieth century (Bloom and Williamson 1998). But this is not the most likely scenario partly because fertility rates are not falling rapidly enough to decrease the region's dependency rate, which is a key to capturing a demographic dividend.

At the same time, young people in sub-Saharan Africa face difficult employment prospects. The majority work in low-productivity jobs, most often in agriculture or in self-employment or household enterprises. They have low earnings, little security, and limited possibilities for upward mobility. A substantial modern wage sector currently exists only in the region's few upper middle-income countries. Educated young people, particularly in these countries, may have better jobs when they do get them but open unemployment for this group is a serious concern. Some forecasts predict that wage

(c) The Author(s). 2018 Open Access This article is distributed under the terms of the Creative Commons Attribution 4.0 International License (http://creativecommons.org/licenses/by/4.0/), which permits unrestricted use, distribution, and reproduction in any medium, provided you give appropriate credit to the original author(s) and the source, provide a link to the Creative Commons license, and indicate if changes were made. 
employment will increase significantly in the coming years with expanding manufacturing and service industries (e.g., McKinsey Global Institute 2012). However, it is overly optimistic to expect major changes in the region's job structure over the next decade, with most young people continuing to work in agriculture and household enterprises (Fox et al. 2013).

What actions are being taken to improve employment and livelihoods for young Africans? Our review finds that the dominant intervention has been skills development programs oriented towards wage employment. This focus does respond to the human capital shortcomings in the region where, despite recent improvements in education, the majority of young people still do not go beyond primary school. However, there are concerns about the quality and the relevance of these programs, especially given the region's employment structure. Nonetheless, upgrading the skills of young people is important both to increase productivity and living standards in agriculture and the household enterprise sector as well as to build a future workforce for the wage sector.

However, to address youth employment, more attention needs to be given to interventions that fall outside the conventional limits of training and other labor market programs. Many young Africans seeking better jobs and livelihoods are constrained by factors that are not typically considered in these programs. These include, for example, a lack of access to credit, land, or productivity-enhancing infrastructure, or by political or social instability, which deter investment and entrepreneurship. In our review, then, we have also included a broader set of interventions relevant for young people seeking their livelihood in self-employment or in agriculture. Programs in these areas are not common nor have they been designed to address the particular needs of young people.

Evidence-based research can play an important role in identifying the barriers young people in SSA face in finding employment and assessing the likely effectiveness of potential policy actions. While there have been some comprehensive regional studies (e.g., Filmer and Fox, 2014; African Development Bank (AfDB) et al., 2012), more detailed, country-level analysis is lacking, in part because of data shortcomings. There are also gaps in knowledge of existing programs, especially those sponsored and undertaken by the private sector, foundations, and NGOs. Much more program evaluation is needed to identify what works in different contexts in the region.

The paper is structured as follows: Section 2 examines demographic trends in sub-Saharan Africa and then profiles youth employment in the region. In Section 3, we review the evidence on interventions to support better jobs for young people. Conclusions are presented in Section 4.

\section{Demographic and youth employment trends}

There is a growing body of empirical analysis on youth employment in sub-Saharan Africa which has benefited from new research and data efforts. However, important gaps remain-for example, in covering agriculture and the non-agricultural informal sector, disaggregating employment outcomes by key variables such as gender, and getting reliable estimates over time. The evidence base is uneven as well: it is strong in some parts of the region, most notably South Africa, but very limited in other parts, such as the Francophone countries of West Africa.

We adopt a broad definition of "employment" in this paper, beyond the traditional notion of wage and salary jobs, usually in the formal sector. Most people in SSA work 
on farms, in very small family enterprises, or in some form of self-employment. So a meaningful conception of employment in the region needs to encompass these different types of jobs, the vast majority of which are in the informal sector.

The definition of "youth" in the sub-Saharan context is also not straightforward. While international norms define it as the 15-24-year-old age group, in this region some international organizations and many national youth policies extend the upper boundary beyond (and often well beyond) 24 years of age. ${ }^{1}$ While this makes sense from the perspective that full transition into adulthood can be a protracted process in SSA, a higher upper boundary risks losing sight of the issues specific to youth, as distinct from the adult population at large. This is especially relevant in sub-Saharan Africa with a very young age profile where extending the definition can result in youth accounting for a large share of the working-age population. ${ }^{2}$ In analysis reported elsewhere (Betcherman and Khan 2015), we have looked at how education and employment patterns of young people evolve with age and at what point they stabilize and start to look similar to adult patterns. While some evidence does show that these transitions can be protracted, much of the data we have reviewed indicates that the conventional 15-24 age group definition is broadly appropriate for sub-Saharan Africa.

\subsection{Demographic trends}

SSA is the youngest region in the world, with a large youth bulge that will continue into the future. The median age is 18 now -7 years younger than South Asia's, the second youngest region-and will climb only to 24 by $2050 .{ }^{3}$ The region's youth cohort is large and growing quickly. Between 2000 and 2015, the 15-24 age group grew by 2.6\% each year on average. According to UN estimates, there were 190 million in this age group as of 2015, and this number is projected to increase at an annual rate of 2.5-2.7\%, reaching 249 million in 2025, and 311 million in 2035. Over this period, SSA's youth cohort will grow by about six million annually.

This youthful profile offers the potential for a demographic dividend, such as was widely recognized as an important contributing factor to East Asia's rapid economic growth over the last third of the twentieth century (e.g., Bloom and Williamson 1998). Certainly, there are many factors that determine whether a youth bulge can accelerate economic development, including whether the conditions for growth and labor demand are present in the industrial and service sectors. But a necessary condition for securing the dividend is to reduce the dependency ratio. This requires significant declines in the fertility rate. It is unlikely, though, that this will occur in SSA. The fertility rate, now around five births per woman, is only projected to decline to the 3.5-4 range by the 2030s. As a result, the dependency ratio will decrease slowly, from the current 85 to 78 in 2025 and 71 in 2035. ${ }^{4}$ In contrast, East Asia's dependency ratio fell from 76 in 1965 to 48 in 2000, driven by a dramatic fertility rate decline from over 5 to 1.5 in this period (Fig. 1).

\subsection{Youth employment trends}

Most empirical analysis of employment in sub-Saharan Africa relies on data from household surveys, such as labor force surveys and living standards measurement surveys. However, regularly repeated labor market surveys are carried out only in 


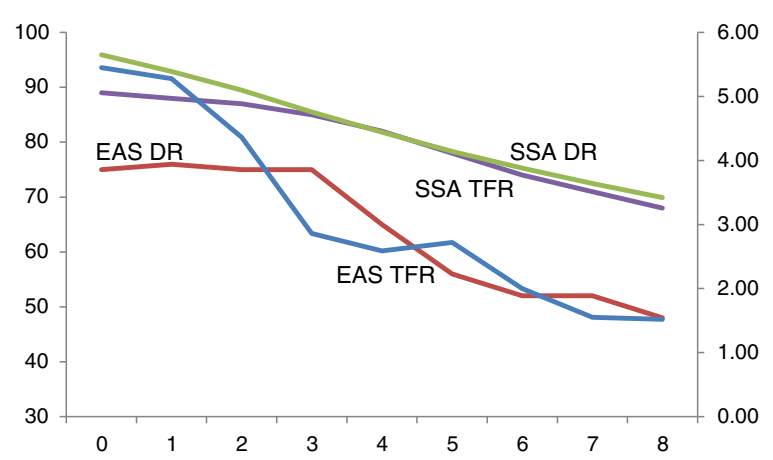

Fig. 1 Total fertility rate and dependency rate, sub-Saharan Africa and East Asia, 5-year periods from start of fertility transition, 1960 for EAS, 2000 for SSA. Note: Left-hand axis is total dependency rate (DR); right-hand axis is total fertility rate (TFR); horizontal axis is number of 5-year period after the start of the fertility transition. Source: United Nations World Population Prospects: The 2012 Revision

Tanzania, Mauritius, and South Africa (Szirmai et al. 2013). In other countries, these surveys are irregular and in some cases, they are not national in coverage. Many small surveys carried out have yielded useful analysis, but their representativeness is not always clear (Szirmai et al. 2013). In recent years, analysis of SSA labor markets has benefited greatly from efforts by international organizations to harmonize existing household surveys (e.g., World Bank), use non-traditional survey sources (e.g., African Economic Outlook, using the Gallup World Polls), ${ }^{5}$ or generate new surveys (e.g., the ILO-MasterCard Foundation School-to-Work Transition Surveys).

According to conventional labor market indicators, youth employment in sub-Saharan Africa actually compares reasonably well with other regions (Table 1). The youth unemployment rate is below rates elsewhere except South Asia and East Asia and the ratio between the youth and adult unemployment rates is the lowest among all regions. A higher proportion of young people in SSA participates in the labor force and is employed than in any other region. Gender differences in youth participation, employment, and unemployment rates are also smaller in SSA than in most other regions (Betcherman and Khan 2015).

Table 1 Summary indicators, youth employment (15-24 years), by region, 2013

\begin{tabular}{lllll}
\hline & $\begin{array}{l}\text { Unemployment } \\
\text { rate }\end{array}$ & $\begin{array}{l}\text { Youth-to-adult } \\
\text { unemployment rate }\end{array}$ & $\begin{array}{l}\text { Labor force } \\
\text { participation rate }\end{array}$ & $\begin{array}{l}\text { Employment } \\
\text { rate }\end{array}$ \\
\hline Sub-Saharan Africa & 11.7 & 2.0 & 53.6 & 47.3 \\
Developed economies & 17.9 & 2.3 & 47.5 & 39.0 \\
$\begin{array}{l}\text { Central and Southeastern } \\
\text { Europe/CIS }\end{array}$ & 18.0 & 2.6 & 42.0 & 34.5 \\
East Asia & 9.8 & 2.7 & 59.3 & 53.5 \\
Southeast Asia and Pacific & 13.3 & 5.3 & 52.2 & 45.2 \\
South Asia & 9.4 & 3.9 & 40.9 & 37.0 \\
Latin America and & 13.2 & 2.7 & 52.4 & 45.5 \\
Caribbean & & & 30.2 & 21.4 \\
Middle East & 29.1 & 3.8 & 33.3 & 25.4 \\
North Africa & 23.9 & 3.3 & &
\end{tabular}

Source: International Labour Office (ILO) (2013) 
However, it is well known that these conventional indicators do not capture labor market outcomes very well in low-income settings, where the wage sector is small, agriculture is the dominant livelihood, and there is little formal social protection. Baah-Boateng (2015) shows that sub-Saharan Africa's low unemployment rates, as defined using ILO standards, misleadingly understate true joblessness because they do not include discouraged workers, those who work in the informal sector as a substitute for unemployment, and workers who are underemployed. According to the World Bank, nearly 95\% of the region's labor force is in countries classified as low-income, lower-middle income, or resource-rich (Filmer and Fox, 2014). In these country groupings, between one half and two thirds of workers are in agriculture with another $20 \%$ or so in household enterprises. ${ }^{6}$ Only about $10 \%$ is in wage employment. It is only in the region's upper middle-income countries, essentially in southern Africa, that a significant wage sector exists, accounting for about $60 \%$ of the labor force. However, only slightly more than $5 \%$ of SSA's total labor force is in these countries (Filmer and Fox, 2014).

The employment challenges facing young people vary in these different types of labor markets. Youth unemployment is extremely high in upper middle-income countries, such as South Africa and Botswana. ${ }^{7}$ In the lower-income countries, open unemployment is relatively rare and underemployment and job quality are the main issues. However, there are no widely accepted and available measures of these latter concepts. ${ }^{8}$ We do know that workers in non-wage employment are more likely to be poor and food insecure, ${ }^{9}$ so some researchers equate these employment forms with "vulnerable" employment. In low-income SSA countries, almost all youth employment is vulnerable by this definition (Hamaguchi et al. 2013). Unemployment may be low but earnings are poor and precarious, and benefits and access to any meaningful formal social protection are essentially non-existent.

While unemployment rates may differ substantially between lower- and middle-income countries, better-educated youth are more likely to be unemployed in both country groups (Table 2). This reflects the fact that the better-educated generally are more likely to be in the wage sector, or to be willing to queue for a job in that sector. However, while there is generally a positive relationship between education and unemployment, individual countries tend to exhibit one of two patterns. In several (e.g., Congo, Ghana, Malawi, Mali, Niger, Nigeria, and Uganda), there is a linear relationship, with youth unemployment rates increasing with more education. In others (e.g., Ethiopia, Congo, South Africa, Senegal, Tanzania), unemployment peaks for those with secondary attainment but declines for those young people with postsecondary education.

\subsection{Will the employment structure change?}

An important feature of labor markets in sub-Saharan Africa, and one which constrains opportunities for youth, is that the structure of employment has not changed much

Table 2 Youth unemployment rates by education, low- and middle-income countries, sub-Saharan Africa, 2009-2010

\begin{tabular}{lllll}
\hline Country category & No education & Basic education & Secondary education & University/tertiary \\
\hline Low income & 7.9 & 12.1 & 15.9 & 18.8 \\
Middle income & 22.7 & 17.5 & 29.5 & 34.6 \\
\hline
\end{tabular}

Source: African Development Bank (AfDB) et al. (2012) 
over recent decades. In other regions, most notably East Asia, structural change-from agriculture to industry and services-has been an important driver of economic development and better jobs. Structural change has been much less important in SSA, with the result that there has been not been significant upgrading of the employment structure (Fox et al. 2013). ${ }^{10}$ Growth in many SSA countries has been driven by commodities and other forces (such as aid) that not only are not labor-intensive, but also do not lead to structural change. ${ }^{11}$ Young people continue to work more in agriculture than in the other sectors (African Development Bank (AfDB) et al., 2012) and, since agricultural productivity is low (Filmer and Fox, 2014), the prospects for good livelihoods in the sector are poor.

An important question is whether the region is now poised to undergo the structural change that will shift employment opportunities increasingly towards better jobs in industry and services. The McKinsey Global Institute (2012) contends that Africa, with its young population and improving education, will imitate the job-creation successes that some developing countries in other regions, especially Asia, have enjoyed. MGI concludes that somewhere between 54 and 72 million stable wage jobs can be created by $2020 .{ }^{12}$ However, projections by Fox et al. (2013) are less optimistic. According to their analysis, only $20 \%$ of the new entrants to the labor force to 2020 will find wage employment; this amounts to about 30 million jobs. ${ }^{13}$

The upper boundary of McKinsey's job creation estimates assumes that Africa could potentially create wage-sector jobs at the pace that East Asian economies did during their period of rapid structural transformation. That seems overly optimistic, given the confluence of factors (demographic, infrastructure, education, policy, etc.) that underpinned the East Asian manufacturing miracle and given the fact that light manufacturing is becoming less labor-intensive. Even when the forecasts by Fox et al. (2013) are adjusted to reflect the possibility that wage employment will increase more rapidly as happened in Asia, they still project that wage jobs will not be near the levels projected by McKinsey. Over the next 10 years, they estimate that only about one quarter of the region's young people will find a wage job and "most young people will end up working where their parents do - in family farms and household enterprises" (Filmer and Fox, 2014: 5).

\subsection{Obstacles to better jobs for youth}

Many of the most important obstacles facing young people in sub-Saharan Africa are not youth-specific and constrain job creation more generally. Infrastructure, governance and corruption, and access to finance are issues almost everywhere (McKinsey Global Institute 2012; African Development Bank (AfDB) et al., 2012). Job creation obstacles can vary depending on the country's level of development and other characteristics (World Bank 2012). For example, in lower-income, agrarian economies, where most people continue to be engaged in farming, low productivity in agriculture is the major constraint to good livelihoods. In middle-income countries, where urban economies are developing, the investment climate and the regulatory environment for labor-intensive business and productive microenterprises, access to finance, and skills are all constraints.

Better youth employment outcomes will require improvements on the demand side-i.e., in the overall economic environment, whether in agriculture, in 
microenterprises, or in the wage sector. However, though these are general issues, some of these demand constraints can disproportionately affect young people. For example, while credit may be a general problem in the region, access is particularly restricted for young entrepreneurs ((Elder and Koné 2014). As well, while SSA tends to have more rigid job security rules than other regions (African Development Bank (AfDB) et al., 2012), these typically have the effect of favoring prime-age workers over youth (Betcherman 2015). ${ }^{14}$

However, issues specific to young people especially come into play on the labor supply side through concerns about the human capital of youth. ${ }^{15}$ Employers identify lack of skills and experience as the main reasons for not hiring young people (African Development Bank (AfDB) et al., 2012). As an illustration, Chinese firms investing in the region find a lack of skills to be a serious constraint and have started to invest significantly in training programs (Bashir 2016). This unmet demand for skills is consistent with the high returns to education in SSA; according to estimates by Montenegro and Patrinos (2014), they are higher than in any other region. Despite improvements in educational attainment, most young people in SSA still do not have much schooling. About $60 \%$ of 15-24-year-olds have not gone beyond primary school and only about $10 \%$ have completed secondary school (Filmer and Fox, 2014).

There are also claims of mismatches between the needs of the labor market and skills offered by young people. Weaknesses include basic, non-cognitive, and vocational skills (African Development Bank (AfDB) et al., 2012). So, although education indicators are improving in the region, many young people remain ill-equipped for the labor market. The relevance of skills as an obstacle to youth employment increases as countries move up the development ladder. It is more important for wage employment but can also constrain productivity and living standards in agriculture and household enterprises.

\section{Youth employment interventions}

This section reviews the literature on interventions to support youth employment in sub-Saharan Africa. ${ }^{16}$ Most programs have focused on skills development for the formal wage sector, particularly in urban areas. Far less attention has been paid to interventions intended to enhance agriculture and micro/household enterprises in the informal sector as sources for youth employment, despite the fact that most young people in the region work in these sectors. As we have seen in the previous section, the barriers young people face in a region as diverse as sub-Saharan Africa are wide-ranging, involving both the supply and demand sides. Therefore, it is important to adopt a broad approach to defining youth employment programs, including some types of interventions that are outside the traditional scope of such programs.

Our review has been limited to post-formal-schooling programs. Interventions have been included if youth are the targeted participants or are very important participants in a non-targeted program. We have concentrated on publicly sponsored interventions, delivered by government or by non-government or private-sector actors in partnership with government. These choices have been made to make our review feasible but we recognize that this methodology excludes some potentially important interventions. ${ }^{17}$

Active labor market programs (ALMPs) constitute the starting point for this review. Almost all sub-Saharan African countries have ALMPs which are either targeted at young people or have significant youth participation. However, in the African context, 
it is important to go beyond ALMPs, which are oriented towards the modern wage sector which employs only a relatively small share of the region's youth. So we have also reviewed programs outside the normal boundaries of youth employment policy that are designed to improve livelihoods for young people in agriculture, in self-employment, and in household or microenterprises.

Using this lens, we have classified youth employment interventions under the following five categories: employment creation; skills development; employment services; self-employment/entrepreneurship; and agricultural livelihoods. ${ }^{18}$

Rigorous evaluations of youth employment programs in the region have been relatively scarce; of the 29 active labor market programs in SSA included in the 2007 Youth Employment Inventory, estimates of net impact had been made for only two (Betcherman et al. 2007). However, in an updated review of youth program evaluations, Kluve et al. (2016) note a recent increase, especially of randomized control trials. Unfortunately, the evaluation evidence is very limited for non-traditional interventions to enhance livelihoods in agriculture and household enterprises. The small numbers of youth program evaluations makes it difficult to rigorously assess the overall quality of the different types of interventions, or what is effective in terms of program design and implementation.

\subsection{Employment creation}

Programs in this category include public works and wage subsidies. Public works programs directly create employment in the short run, while wage subsidies provide incentives to employers to hire targeted workers. However, in sub-Saharan Africa as elsewhere, public works programs are most often designed to provide a safety net; improving employability is typically a secondary objective. So targeting is usually oriented towards the poor. Wage subsidy programs, on the other hand, often do have specific demographic targets, such as youth.

\subsubsection{Public works}

The international evaluation evidence suggests that public works programs can be successful anti-poverty interventions when they are well-targeted and administered (Subbarao et al. 2013). However, the few existing evaluations do not show post-program labor market benefits such as lower unemployment, higher earnings, or an easier transition to formal-sector jobs (Card et al. 2010 and 2015; International Labour Office (ILO), 2010; Betcherman et al. 2007; Betcherman et al. 2004). The most likely explanation is that public works programs do not develop skills that are needed in the labor market. As well, there may be a negative stigma associated with participation.

A number of countries in sub-Saharan Africa have implemented public works programs, both as an ongoing element of the social protection system (e.g., South Africa, Ethiopia, Senegal) or as a temporary intervention to mitigate the effects of a shock like the food, fuel, and financial crises in the 2006-2009 period (e.g., Liberia, Sierra Leone, Guinea). Although there have been very few evaluations, the evidence for SSA seems to be consistent with the international evidence; public works programs are more successful as a means of transferring cash than as a cost-effective way of creating employment (African Development Bank (AfDB) et al., 2012).

Although most studies have defined success for public works (and other ALMPs) in terms of increasing employment and/or earnings, these programs may have positive 
social returns if they contribute to other goals, such as social cohesion, as suggested by the World Development Report on Jobs (World Bank 2012). Several SSA countries (e.g., Sierra Leone) have introduced public works programs soon after conflicts have ended. While rigorous evaluations have not been carried out, such interventions that provide even short-term work for youth can contribute to the rebuilding of society by offering young people an alternative to participation in further conflict, by providing income and by building infrastructure (World Bank 2012).

\subsubsection{Wage subsidies}

These hiring incentives are often targeted at youth, in recognition of the fact that young people face difficulties in establishing a foothold in the labor market because they lack on-the-job skills and experience. These gaps have been cited by SSA firms as the main reasons for not hiring youth (African Development Bank (AfDB) et al., 2012). Evaluations of wage subsidies, largely in developed countries, have shown that they can have a positive impact on post-program employment in general, and for youth in particular (Kluve et al., 2006; Betcherman et al. 2007). However, it is not clear that the overall employment impacts would remain positive if displacement and windfall costs were fully captured. It is generally believed that these costs can be significant.

Subsidies are an instrument that is essentially restricted to formal wage sectors. Since these sectors account for only a small minority of employment in most SSA countries, it is not surprising that the region does not have much experience with this type of incentive. One exception is South Africa where the government has experimented with youthtargeted wage subsidies. An RCT evaluation showed that these subsidies induced firms to hire more young people, although the positive impacts disappeared after the subsidy period was over (Rankin 2013; McKenzie 2017). The evaluation also noted that the take-up of the subsidy offer by firms was quite low, seemingly because of administrative barriers within firms as well as their concerns about the legitimacy of the subsidy (Rankin 2013).

Overall, the findings suggest that employment creation through public works programs and wage subsidies have had limited effect on youth employment in sub-Saharan Africa, the former mostly providing a short-term safety net and the latter limited to a fairly narrow segment of the youth workforce.

\subsection{Skills development}

Skills development is the most common youth employment intervention in subSaharan Africa. These programs, offered outside the formal education system, include second-chance education programs, classroom-based technical and vocational education and training, workplace training, formal and non-formal apprenticeship schemes, soft- and life-skills training, and access to credit and financial incentives for employers to provide workplace training.

The international evaluation literature suggests a mixed record regarding the effectiveness of training programs for youth. Card et al. $(2010,2015)$ conclude that classroom and on-the-job training can have positive impacts on employment, especially over the longer run (e.g., after 2 years post-training); however, they found that youth tend to benefit less than adults from these programs in their 2010 meta-analysis, but not in their 2015 study. Looking at youth training programs, in particular, Betcherman et al. (2007) also find mixed results, though impacts seem to be more positive in developing 
than developed countries. An analysis by the Inter-American Development Bank of their own youth training programs found slightly more positive results (Ibarraran and Shady 2009). The recent meta-review of youth employment programs by Kluve et al. (2016) found that training, along with entrepreneurship programs, had the most positive impacts in low- and middle-income countries.

Skills development programs potentially have an important part to play in improving employment prospects for youth in SSA, since many young people remain poorly educated, without the skills to succeed in the labor market. In addition, some studies talk about skills mismatches, i.e., where educated youth do not have the competencies required by employers (e.g., African Development Bank (AfDB) et al., 2012). The development of relevant skills-both technical and non-cognitive or "soft" skills-is not just important for the formal sector, it is also critical for the informal sector where most young Africans work and will continue to work (Adams et al. 2013). Returns to technical education and training may be particularly high in sub-Saharan Africa as illustrated by a study of eight countries which found higher returns in five countries for vocational training than for general secondary education (African Development Bank (AfDB) et al., 2012).

Evaluations are too scarce for a rigorous assessment of the effectiveness of training programs in the region. However, there have been a few recent evaluations indicating that skills training, when combined with mentoring and/or access to finance, has positive results. For example, the Economic Empowerment of Adolescent Girls (EPAG) program in Liberia provided classroom-based training followed by 6 months of follow-up support and reported a $47 \%$ increase in employment (Adoho et al. 2014). However, the overall quality of youth training programs is considered to be weak (African Development Bank (AfDB) et al., 2012). Much of the training that is available is oriented towards white-collar jobs in urban areas, which represent a relatively small aspect of total labor demand. The large numbers of youth in rural areas, as well as workers in informal employment, have much less access to training opportunities (Adams et al. 2013).

One message from the evaluation literature is that private-sector involvement can improve the success of training by increasing the relevance of programs to the needs of the labor market and, to some extent, by improving quality through competition and innovation. The literature suggests that public-private partnerships can be helpful in improving quality and access (United Nations Economic Commission for Africa (UNECA), 2011). Examples of such partnerships, however, are limited in SSA. The private sector can also sponsor and deliver training independent of government programs though it is not clear how much employer-based training occurs in the region. According to the African Economic Outlook report on youth employment, sub-Saharan African firms provide very little training compared to firms in other developing-country regions (African Development Bank (AfDB) et al., 2012).

The private sector is also involved in skills development by providing training through commercial institutes; however, the extent to which these trainers are used for the delivery of vocational training varies by country. Commercial trainers are often preferred over public training institutions by policymakers and donors. However, Atchoarena and Esquieu (2002) point out that in SSA, private training institutions have not always had a better performance. There can be a wide variation in the quality of private trainers, especially if standards are not set and carefully monitored. So, even where 
private delivery of skills development programs is encouraged, governments still have a critical role, providing regulatory supervision in addition to setting the overall policy framework and funding (Department for International Development (DFID), 2011).

Training for workers in the informal sector is obviously very pertinent in a region where most people are employed in that sector. In some countries, such as Uganda, there are growing numbers of privately run, unregistered, and small-scale non-formal training outfits which are part of the informal sector themselves and serve workers in that sector. However, Adams et al. (2013) conclude that workers in informal employment are largely underserved by training opportunities and that this situation needs more attention. The main source of skills development for informal-sector workers in SSA continues to be informal apprenticeships, which have a long tradition in the region. However, there are many concerns about how much skills development actually occurs in these apprenticeships, mostly undertaken between a master craftsman and apprentice, partly because of the low level of education of most participants and partly because the content is often limited to traditional learning (Adams et al. 2013). In response, several countries, including Kenya, Nigeria, and South Africa, have now introduced apprenticeship programs that integrate theoretical learning with work experience (United Nations Economic Commission for Africa (UNECA), 2011).

In a region where many young people have little or no education, there is a strong rationale for second-chance programs. These programs can be particularly needed in countries where conflict has interrupted or ended schooling for many. Second-chance programs include accelerated learning programs and other non-formal education programs that focus on the acquisition of basic skills such as literacy, oral expression, numeracy, and problemsolving and may or may not lead to equivalency qualifications. However, second-chance programs can be expensive, and it is difficult to assess their cost effectiveness because of a lack of outcome data (Filmer and Fox, 2014).

Skills development programs are by far the most popular intervention for supporting youth employment in sub-Saharan Africa. However, their effectiveness is uncertain because of quality concerns and because of a focus on training for the relatively small formal wage sector in most countries. In any event, there is a need for more evaluation evidence to understand how skills development can effectively prepare the region's young people not only for that sector but also for other livelihoods where many of them will work. Innovation can play a decisive role in providing this training, both through the use of ICT and through public-private partnerships.

\subsection{Employment services}

Employment services, such as job search assistance, can improve the functioning of the labor market through better information and intermediation between jobseekers and employers. Traditionally, employment services have been provided by public agencies but private agencies are increasingly important players. The evaluation record of employment services internationally is generally positive. They tend to improve employment and earnings prospects for participants and, since they are less costly than other types of interventions, their cost-effectiveness ranks well in comparison to other ALMPs (Kluve et al., 2006; Card et al. 2010; Betcherman et al. 2004). However, the usefulness of employment services tends to be limited, improving employment more for 
the skilled than the unskilled (Kluve et al., 2006). Their benefits are also greatest in the short run and tend to diminish over time (Card et al. 2015).

Employment services are most useful for the formal wage sector and have a smaller influence in countries where much of the employment is in agriculture and selfemployment (World Bank 2012). They also tend to be more relevant in countries with unemployment insurance systems since they fulfill a function of assisting registered jobseekers. Not surprisingly, employment services play a small role in SSA countries. An experts survey in 37 countries in Africa (SSA and North Africa) carried out for the African Economic Outlook found that public agencies were estimated to reach more than $50 \%$ of young jobseekers in only seven countries and in only one did private agencies appear to have this reach (African Development Bank (AfDB) et al., 2012). Furthermore, any coverage by employment agencies is in urban areas. Most young people rely on family and friends to search for work (Elder and Koné 2014).

In recent years, there have been a few RCT evaluations of employment service interventions in SSA targeted at youth. These include skills certification in Ethiopia and Uganda, and job fairs and a transport subsidy in Ethiopia. The results of these evaluations, summarized by McKenzie (2017), confirm that employment services are a low-cost intervention; however, there is no evidence of significant positive impacts on employment.

While formal job search methods and employment assistance services may be rarely used by young people in SSA, this does not mean that information failures are not a problem. Just under half of the experts surveyed for the African Economic Outlook ranked lack of labor market information as a challenge for young people, although only a small percentage of young people themselves rated lack of awareness of available jobs as an issue (African Development Bank (AfDB) et al., 2012).

ICTs, most obviously mobile and smartphones, can potentially play a role in improving labor market information and helping young people search for jobs and other livelihood opportunities, including outside the modern wage sector. Technology can also connect youth with employment opportunities in other countries. It also offers them a chance of being employed in global markets without leaving their home countries. ${ }^{19}$ To succeed in this emerging market, however, sub-Saharan African countries need to ensure an effective regulatory framework, and the necessary technological infrastructure.

Overall, the evidence shows that formal job placement services, both public and private, play only a small role in the region's labor markets and, where they are present, they largely focus on more educated urban youth. Yet, there is a need for better information and intermediation. Technological innovations that can potentially reach further into the informal sector, as well as target opportunities for youth beyond national borders, can play a role. This opens up a gap for in-depth research into this area of intervention in SSA.

\subsection{Self-employment/entrepreneurship}

Programs in this category address two different objectives. One is to support selfemployment as a means for poverty reduction, with interventions that typically include some form of microfinance, at times in combination with technical assistance. The other is encouraging entrepreneurial activity, not primarily focused on supporting basic 
livelihoods but rather helping youth with entrepreneurial potential with the financial and technical needs they may have to start and develop their own businesses. Most self-employed youth undoubtedly fit into the first category. However, there does seem to be a considerable amount of true entrepreneurial potential among African youth. ${ }^{20}$

The evaluation evidence on self-employment and entrepreneurship interventions for youth is very limited, especially in developing countries. However, as was noted earlier, the meta-analysis of youth programs by Kluve et al. (2016) identified entrepreneurship programs, along with training, as the most effective interventions in low- and middleincome countries. While an extensive body of evidence is lacking, most researchers agree on two factors that are important for successful youth self-employment and entrepreneurship programming (African Development Bank (AfDB) et al., 2012). One is targeting, since not all young people are inclined or suited to starting their own business. The other is providing both financing and technical support, since both capital and know-how can be obstacles to young entrepreneurs.

Since the wage labor market in almost all SSA countries generates very few jobs compared to the supply of labor, many young people have little choice but to create their own jobs. But they face several constraints in starting, sustaining, and expanding their businesses, the biggest being lack of finances. The ILO-MasterCard Foundation School to Work Transition Surveys show that most young people who have started businesses do so with very little capital, drawing on their own savings in most cases. Very few receive financial assistance from banks or microfinance institutions for either start-up or operating purposes. Yet, self-employed youth in all countries included in the School to Work Transition Surveys identified a lack of access to financial capital as their main challenge to doing business (Elder and Koné 2014).

Microcredit is a popular instrument in much of the developing world for providing access to financing for the self-employed and small entrepreneurs. There has been very little serious analysis of microcredit in sub-Saharan Africa but available research shows mixed and inconclusive results (Bertrand and Crepon 2014). In any event, the actual impact of microcredit to youth in sub-Saharan Africa is limited particularly since the demand for microfinance in the region is much higher than the supply. And microfinance institutions tend to lend to adults rather than youth, who are seen as riskier clients because of their lack of experience as borrowers and as entrepreneurs (Shah et al. 2010). Microfinance products need to be adapted to the needs of young people if they are to become a more relevant instrument. This might include modifications in lending conditions and the provision of training and counseling services to accompany the financial assistance (Shah et al. 2010).

A less frequently discussed obstacle to self-employment and entrepreneurship is the regulatory environment. Business regulations and urban policies may not seem directly relevant to a youth self-employment strategy, but they can matter. In this respect, many SSA countries have been introducing reforms to improve the business climate, which should support entrepreneurs, including youth. For instance, according to the 2015 Doing Business Report, sub-Saharan Africa accounted for the largest number of regulatory reforms for making it easier to do business. More than 70\% of the region's countries had carried out at least one reform (World Bank Group 2015). Most of the reforms in SSA are associated with reducing complexity and the costs of doing business. 
Urban policies can also affect youth self-employment and the success of micro- and household enterprises where most young people in cities work. Yet the environment can be a very negative one, because of formal policies (e.g., use of public space, zoning, fees) or informal practices (e.g., harassment of small vendors). Informal street trading, for instance, is a large and rapidly growing form of entrepreneurship in urban areas of SSA that requires an enabling environment to thrive. In Tanzania, Ghana, Kenya, and South Africa, street vendors have formed informal associations that engage and negotiate with municipal authorities to be able to access formal training, finances, and infrastructure to support their trade (Filmer and Fox, 2014).

Recent analysis also highlights how innovative new business models such as technology advancement and value-chain development can encourage youth enterprises. Mobile banking systems are a good example of a new technology that has very quickly taken root among young people who have used it as a means of employment by selling airtime or pay-per-use phones. The private sector has played an important role in encouraging the use of such technology by providing technical assistance and technological expertise. For instance, Safaricom's M-PESA in Kenya was one of the first mobile banking applications to be launched on the continent, followed by MAP Mobile banking in Uganda.

Given the scale of self-employment in SSA, its importance to poverty reduction, and its entrepreneurial potential, programs and policies directed towards self-employment and entrepreneurship should be an important part of youth employment strategies in the region. Access to capital is the number one barrier to be addressed. However, skills and technological advancement, as well as a supportive regulatory environment, also matter. It is also important to assemble evaluation evidence in order to learn more about what specific interventions can help young entrepreneurs in a cost-effective manner.

\subsection{Agricultural livelihoods}

Most young Africans work in agriculture so the livelihoods of young people in the region will depend heavily on improving the returns to farming. The low incomes and productivity in agriculture are due to a variety of factors including the small scale of farms, uncertain land tenure, low-yield crops, poor infrastructure, lack of mechanization, and low-skill farming practices in general (World Bank 2012; Filmer and Fox, 2014). Addressing these, and improving youth livelihoods in agriculture in the process, requires a range of interventions that fall well outside the traditional envelope of youth employment programs. Since accelerating growth in agriculture has not been framed as part of SSA's youth employment challenge, there is very little literature and virtually no evaluation evidence to inform policy-makers about what types of interventions can improve the prospects of young people in the sector. ${ }^{21}$

The future of youth livelihoods in agriculture has some particular challenges. Dwindling land resources, land grabs, inheritance practices, limited profitability, and lack of investment in technology and infrastructure are combining to push many young people out of agriculture or, at least to create reluctance to pursue farming-based livelihoods (White 2012; Sumberg et al. 2012). Changing perceptions of traditional employment, the physically demanding nature of farming, and higher expectations also mean that agriculture holds less attraction for many rural youth, who want to transition to urban jobs and lifestyles. 
Filmer and Fox (2014) identify four priorities to provide better livelihoods for young people in agriculture: skills, land policy, credit, and infrastructure. In addition to overcoming the low educational attainment of rural youth, the acquisition of farming skills in SSA traditionally has been hindered by the limited effectiveness of agricultural vocational training institutions and extension services. But some program evaluations are now showing positive employment effects of agricultural training programs (Bertrand and Crepon 2014). Second, land is a major issue for young people, and increasingly so as Africa moves from being a land-abundant continent to a land-scarce one. Rural youth depend on family plots but these get sub-divided into smaller and smaller parcels over time (Cling et al. 2007). The problem is exacerbated where families do not have secure control over the lands they farm.

Access to credit is also a major issue for young farmers, especially because they typically do not have sources of collateral. Some countries in sub-Saharan Africa are attempting to provide alternative forms of collateral to young farmers such as movable property and warehouse receipts (Filmer and Fox, 2014). Finally, the provision of rural infrastructure and modern technology can be key elements in creating opportunities for rural youth (Bennell 2010). Services such as transport, storage facilities, and modern irrigation practices are essential in attracting rural youth to agriculture and increasing their productivity.

The FAO is helping governments in the development of public-private partnerships fostering youth inclusion in agriculture and in the design of youth-friendly and climatesmart methods for technical and vocational education and training, e.g., Junior Farmer Field and Life Schools programs. In various SSA countries, including Senegal, Uganda, and Nigeria, FAO is supporting interventions to promote decent rural employment for youth (Food and Agriculture Organization (FAO), 2016).

Ultimately, agriculture will need a great deal of innovation to keep young people in the sector and to ensure that livelihoods through farming and related agribusiness activities improve. Research does suggest that the younger generation is more open to new crops and technologies that produce a higher yield than older farmers. Therefore, special agricultural extension services targeting rural youth can be effective in both improving the quality of rural youth employment and raising agricultural productivity in general.

Innovation can take the form of new seeds, fertilizers, and other methods (World Bank 2012). It can also occur through new products and markets, as well as new opportunities further up the value chain in food processing and distribution. Public sector involvement is a key to such innovation. New products and markets require research and coordination, which typically comes from government. Sub-Saharan Africa does not have a strong record in this area but there have been some effective research collaborations that have led to improved varieties of cotton and cassava (World Bank 2012).

While the development of agriculture and related businesses typically has not been seen as part of strategies to improve youth employment, these are complementary goals in SSA. If interventions can help young people develop the needed skills, access land and credit, and upgrade infrastructure and technology, the future could be more promising.

\section{Conclusions}

Youth employment is understandably a high-priority issue throughout sub-Saharan Africa. The social benefits can be high if the region's young people are engaged in 
productive and rewarding work. But the costs will be high if they are not. ${ }^{22}$ The demographic situation only magnifies the importance of the issue.

Youth employment is a many-sided challenge in sub-Saharan Africa. Unemployment is high among well-educated young people, especially in the region's upper middle-income countries. However, the labor-related difficulties young people face is manifested most in underemployment and low-quality work in agriculture, household enterprises, and other types of informal employment. Although there is an optimistic view that the region is poised to create substantial numbers of good jobs for young people in the modern wage sector, it is realistic to expect that most of today's youth will be working in agriculture and in household and micro-enterprises in the foreseeable future. So, the region's jobs challenge includes both improving productivity and livelihoods in these sectors while, at the same time, establishing the foundations for more opportunities in wage employment.

This will require addressing a diverse set of obstacles. In our review of interventions in the region, we have found that skills development programs dominate youth employment strategies. It is true that, despite improvements in educational attainment, a lack of skills or mismatched skills are problems facing many young people. So training and other forms of non-formal education should be part of any effort to improve youth employment outcomes. However, most programs are oriented towards skills for the formal wage sector which will continue to account for only a relatively small share of total employment in most countries in the region.

Many of the barriers young people face stem from weak fundamentals that constrain job creation and income generation more generally in much of the region. These include poor infrastructure, weak governance and corruption, regulations that drive up the costs of doing business, and limited access to credit. While youth employment strategies cannot address all of these challenges, they should go beyond standard active labor market programs to include, for example, interventions that encourage and support youth self-employment and entrepreneurship and programs that improve productivity and livelihoods in agriculture. To this point, youth employment strategies have not been framed in this way.

Finally, better data and research are key to designing and implementing evidencebased policy to improve youth employment outcomes in SSA. Currently, an understanding of youth employment prospects is hampered both by data limitations and by a lack of appropriate indicators to measure labor market outcomes in low-income and agrarian-based economies. Information on interventions is spotty. Most importantly, more rigorous evaluations of programs are needed. These should include not only training and other active labor market programs, but also interventions that may be outside the traditional employment envelope but could be very important for the livelihoods of young people in sub-Saharan Africa.

\section{Endnotes}

${ }^{1}$ For example, the African Youth Charter defines youth as between 15 and 35 years and most national youth policies define young people as individuals aged up to between 29 and 40. According to the Economic Commission for Africa (United Nations Economic Commission for Africa (UNECA), 2011: 69), these broad definitions reflect "the challenges faced by African youth in effectively integrating into society, finishing school, getting married and gaining financial independence." 
${ }^{2}$ If the upper boundary is 29 , the youth category represents slightly more than half of the region's working-age population, and if it is extended to 34 , the share rises to almost two thirds.

${ }^{3}$ Population figures cited in the text come from the United Nations World Population Prospects: The 2015 Revision. Projections cited are based on the medium-fertility scenario.

${ }^{4}$ It should be noted that demographic trends do differ within SSA, with Southern Africa much more advanced in the fertility transition that the Eastern, Middle, and Western African sub-regions.

${ }^{5}$ The Gallup World Polls may be an unusual source of data for labor market analysis, but they are a useful addition, given the general data limitations in the region. Results using this source that are cited in this paper include data from 39 SSA countries and regions. The samples are nationally representative for the population aged 15 and over, but for the youth population (15-24), results are only indicative at the national level and are representative at the country-group level.

${ }^{6}$ Household enterprises are informal businesses outside agriculture that are "own-account" or self-employment operations, which may have family members contributing. For a detailed analysis of household enterprises in SSA, see Fox and Sohnesen (2012).

${ }^{7}$ In 2014, the youth unemployment rates in South Africa and Botswana were 53 and $34 \%$, respectively (ILO Key Indicators of the Labour Market).

${ }^{8}$ Probably the most common definition is hours-based, where underemployment is identified by employment below a certain number of hours (e.g., $40 \mathrm{~h}$ in a week) and a willingness to work more hours. However, as Ranis and Gollin (2014) point out, hours may not be a good indicator of underemployment because some workers may work very long hours just to survive. They suggest that underemployment may be better defined by employment at very low marginal productivity and earnings, perhaps indicated by the percentage of the workforce earning less than the minimum wage. Using data from the 1-2-3 Surveys in Francophone country capital cities, Ranis and Gollin (2014: Table 2.5) show that the low-wage definition generates much higher underemployment rates than the hours-based definition.

${ }^{9}$ In low-income countries, youth in "vulnerable" employment have the highest level of food insecurity, not only higher than wage employees but also higher than students and the unemployed (African Development Bank (AfDB) et al., 2012).

${ }^{10}$ This is despite fairly strong economic growth. Average annual GDP growth averaged 5.4\% in the region between 2000 and 2014 (World Bank Group, 2015).

${ }^{11}$ Baah-Boateng (2016) argues that the structure of the region's economic growth, which has been largely driven by resource extraction, has not contributed to employment compared to a scenario where growth might have been driven by services and manufacturing which have much higher employment elasticities.

${ }^{12}$ One potential source of wage jobs could be in labor-intensive, light manufacturing where it has been argued that sustained wage increases in coastal China will price that region out of this type of production and create new opportunities elsewhere in the developing world. However, there are many reasons to doubt that this will occasion a large shift of manufacturing jobs outside Asia. See http://www.economist.com/news/ leaders/21646204-asias-dominance-manufacturing-will-endure-will-make-developmentharder-others-made 
${ }^{13}$ According to Fox et al. (2013), the main difference is that their forecasts are based on sub-Saharan Africa specific data while MGI "uses fast-growing developing and emerging market countries in other continents to project the employment profile" (p. 21).

${ }^{14}$ Francophone countries, in particular, have very protective labor market rules (Cling et al. 2007). However, it should be noted that the overall impact of labor regulations in SSA is minimized by the high degree of informality.

${ }^{15}$ Health as well as education is a factor. Poor health and nutrition limit the potential of many young people to accumulate skills and to apply them at work (Hamaguchi et al. 2013; Ranis and Gollin 2014).

${ }^{16}$ In this review, we have surveyed the information that is available from international organizations and both national and international academics and research centers.

${ }^{17}$ Most obviously, formal education is extremely important in determining youth employment prospects, but covering the vast literature on formal education and its links with employment was beyond the scope of our work. We have also only touched upon product and labor market regulations. In terms of program delivery, private actors, such as corporations and foundations, are playing an increasingly important role independent of government but these efforts are not yet well documented.

${ }^{18}$ Programs may offer multiple services that can fit into more than one of these categories. There is some evidence of multiple-service programs in SSA, most often incorporating training into self-employment programs (Rother 2006). However, they do not appear to be very common and certainly are not as prevalent as in some other regions, especially Latin America, with its Jovenes and successor programs.

${ }^{19}$ One example is call center employment in South Africa, which currently stands at around 200,000. Policymakersare interested in how this work might employ disadvantaged people with limited alternative opportunities (Wade and Rogerson 2014).

${ }^{20}$ According to the Global Entrepreneurship Monitor, which is based on surveys in 73 countries, entrepreneurial propensity and activity rates are high among youth in most of the SSA countries included (Singer et al. 2015). Where policymakers can identify young people with high entrepreneurial potential and provide the support they need, the social return could be considerable.

${ }^{21}$ However, Bertrand and Crepon (2014) do note that a number of randomized experiments are now being carried out on agricultural interventions in the region.

${ }^{22}$ For a discussion of the range of negative consequences from youth unemployment, see O'Higgins (2015).

\section{Acknowledgements}

The authors acknowledge the financial support of the International Development Research Centre and the MasterCard Foundation in undertaking this research. The paper has benefited from comments from Martha Melesse and Arjan de Haan, as well as comments from an anonymous reviewer and the editor.

Responsible editor: David Lam

Funding

Grant from International Development Research Centre

Availability of data and materials

Literature review; not applicable

Ethics approval and consent to participate

Not applicable

Consent for publication

Not applicable 


\section{Competing interests}

The IZA Journal of Development and Migration is committed to the IZA Guiding Principles of Research Integrity. The authors declare that they have observed these principles.

\section{Publisher's Note}

Springer Nature remains neutral with regard to jurisdictional claims in published maps and institutional affiliations.

\section{Author details}

${ }^{1}$ School of International Development and Global Studies, University of Ottawa, 120 University Ottawa, Ottawa, ON K1M 1C5, Canada. ${ }^{2}$ Ottawa, Canada.

Received: 27 April 2017 Accepted: 25 January 2018

Published online: 12 July 2018

\section{References}

Adams AV, Johansson de Silva S, Razmara S. Improving skills development in the informal sector: strategies for sub-Saharan Africa. Washington, DC: World Bank; 2013.

Adoho, F, Chakravarty S, Korkoyah D, Lundberg M, Tasneem A (2014) The Impact of an Adolescent Girls Employment Program: The EPAG Project in Liberia, World Bank Policy Research Working Paper no. 6832, Washington, DC.

African Development Bank (AfDB), OECD Development Centre, United Nations Development Programme, United Nations Economics Commission for Africa. African economic outlook 2012. Paris: OECD Publishing; 2012.

Atchoarena D, Esquieu P. Private technical and vocational education in sub-Saharan Africa: provision patterns and policy issues. Paris: UNESCO International Institute for Educational Planning; 2002.

Baah-Boateng W. Unemployment in Africa: how appropriate is the global definition and measurement for policy purpose. Int J Manpow. 2015;36:650-67.

Baah-Boateng W. The youth unemployment challenge in Africa: what are the drivers? Econ Labour Relations Rev. 2016; 27:413-31.

Bashir S. China's contribution to skills development in sub-Saharan Africa. Afr Technopolitan. 2016;5:44-55.

Bennell P. Investing in the future: creating opportunities for young rural people. Rome: International Fund for Agricultural Development; 2010.

Bertrand M, Crepon B. Microeconomic perspectives. In: Hino H, Ranis G, editors. Youth and employment in sub-Saharan Africa: working but poor. New York: Routledge; 2014.

Betcherman G. Labor market regulations: what do we know about their impacts in developing countries? World Bank Res Obs. 2015;30:124-53.

Betcherman G, Godfrey M, Puerto S, Rother F, Stavreska A. A review of interventions to support young workers: findings of the youth employment inventory, Social protection sector discussion paper 0715. Washington, DC: World Bank; 2007.

Betcherman G, Khan T. Youth employment in sub-Saharan Africa: taking stock of the evidence and knowledge gaps. Ottawa: International Development Research Centre and MasterCard Foundation; 2015.

Betcherman G, Olivas K, Dar A. Impacts of active labor market programs: new evidence from evaluations with particular attention to developing and transition countries, Social protection sector discussion paper 0402. Washington, DC: World Bank; 2004

Bloom DE, Williamson JG. Demographic transitions and economic miracles in emerging Asia. World Bank Res Obs. 1998;12:419-55.

Card D, Kluve J, Weber A. Active labour market policy evaluations: a meta-analysis. Econ J. 2010;120:F452-77.

Card D, Kluve J, Weber A (2015) What works? A meta analysis of recent active labor market program evaluations. IZA discussion paper no. 9236. Bonn.

Cling JP, Gubert F, Nordman CJ, Robilliard AS (2007) Youth and labour Markets in Africa: a critical review of the literature. Working paper no. 49. Agence Française de Développement, Paris.

Department for International Development (DFID). Engaging the private sector in skills development. London: DFID Practice Paper; 2011

Elder S, Koné KS (2014) Labour market transitions of young women and men in sub-Saharan Africa. W4Y publication series no. 9. ILO and MasterCard foundation, Geneva.

Filmer D, Fox L. Youth employment in sub-Saharan Africa. Washington, DC: Agence Française de Développement and World Bank; 2014

Food and Agriculture Organization (FAO). FAO the impact of the second poverty decade on rural employment and poverty eradication, Intervention at meeting on employment and decent work for poverty eradication, in support of the second UN decade for the eradication of poverty (2008-2017). Bangkok; 2016.

Fox L, Haines C, Huerta Muñoz J, Thomas A. Africa's got work to do: employment prospects in the new century, IMF working paper WP/13/201. Washington, DC; 2013

Fox L, Sohnesen TP. Household Enterprises in sub-Saharan Africa: why they matter for growth, jobs, and livelihoods, Policy research working paper no. 6184. Washington, DC: World Bank; 2012.

Hamaguchi N, Henstridge M, Hino H, Mwabu G, editors. Empowering young Africans to live their dreams, Report to the fifth Tokyo international conference on African development. Tokyo: Japan International Cooperation Agency; 2013.

Ibarraran P, Shady DR. Evaluating the impact of job training Programmes in Latin America: Evidence from IDB funded operations. J Dev Effectiveness. 2009;1(2):195-216.

International Labour Office (ILO). Global employment trends for youth 2010. Geneva: ILO; 2010.

International Labour Office (ILO). Global employment trends for youth 2013. Geneva: ILO; 2013.

Kluve J, et al. Active labour market policies in Europe. Springer: Berlin. 2006. 
Kluve J, et al. Interventions to improve the labour market outcomes of youth. A systematic review of training, entrepreneurship promotion, employment services and subsidized employment interventions. IZA Discussion Paper No. 10263. Bonn. 2016

McKenzie D. How Effective are Active Labor Market Programs in Developing Countries? A Critical Review of Recent Evidence. Policy Research Working Paper 8011, Washington, DC: Development Research Center, World Bank; 2017. McKinsey Global Institute. Africa at work: job creation and inclusive growth: McKinsey and Co.; 2012

Montenegro CE, Patrinos HA. Comparable estimates of returns to schooling around the world, Policy research working paper no. 7020. Washington DC: World Bank; 2014

O'Higgins N. Youth unemployment. IZA policy papers 103. Bonn: Institute for the Study of Labor (IZA); 2015.

Ranis G, Gollin D. Macroeconomic perspectives. In: Hino H, Ranis G, editors. Youth and employment in sub-Saharan Africa: working but poor; 2014

Rankin N (2013) The impact of youth employment incentives and wage subsidies: results of a trial run. http://www.econ3×3. org/article/impact-youth-employment-incentives-and-wage-subsidies-results-trial-run. Accessed 19 Oct 2017.

Rother F. Interventions to support young workers in sub-Saharan Africa. Washington DC: World Bank; 2006. http:// documents.worldbank.org/curated/en/693371468314689941/pdf/406060AGR0Young0workers01PUBLIC1.pdf. Accessed 14 Dec 2016

Shah A, Mohammed R, Saraf N, Nigam R (2010) Microfinance Services for Youth in the sub- Saharan African region. Warwick Social Enterprise and Microfinance Society and the Student Microfinance \& Development Initiative. http:// juventudruralemprendedora.procasur.org/wp-content/uploads/2013/08/Microfinance-Services-for-Youth-in-the-SubSaharan-African-Region.pdf. Accessed 14 Dec 2016.

Singer S, Amoros JE, Moska Arreola D. Global entrepreneurship monitoring: 2014 global report. London: Global Entrepreneurship Monitoring; 2015.

Subbarao K, del Ninno C, Andrews C, Rodriguez-Alas C. Public works as a safety net: design, evidence, and implementation. Washington, DC: World Bank; 2013.

Sumberg J, Anyidoho NA, Leavy J, te Lintelo DJH, Wellard K. Introduction: the young people and agriculture 'problem' in Africa. IDS Bull. 2012;43:1-8.

Szirmai A, Gebreeyesus M, Guadagno F, Verspagen B (2013) Promoting productive employment in sub-Saharan Africa: a review of the literature. UNU-merit working paper series no. 2013-062, Maastricht.

United Nations Economic Commission for Africa (UNECA). Africa youth report 2011: addressing the youth education and employment nexus in the new global economy. Addis Ababa: UNECA; 2011.

Wade RP, Rogerson CM. South Africa's call centre industry: the emerging challenges of a growing destination in the global south. Mediterranean J Soc Sci. 2014;5:208-17.

White B. Agriculture and the generation problem: rural youth, employment and the future of farming. IDS Bull. 2012:43(6):9-19.

World Bank. World development report 2013: jobs. Washington, DC: World Bank; 2012.

World Bank Group. Doing business 2015. Washington, DC: World Bank; 2015.

Submit your manuscript to a SpringerOpen ${ }^{\odot}$ journal and benefit from:

- Convenient online submission

- Rigorous peer review

Open access: articles freely available online

- High visibility within the field

Retaining the copyright to your article

Submit your next manuscript at $>$ springeropen.com 